\title{
Management of hepatic coma complicating viral hepatitis
}

\author{
R. C. PIROLA, J. M. HAM, AND R. G. ELMSLIE \\ From the Department of Medicine, University of New South Wales, and the Department \\ of Surgery, Prince Henry Hospital, Sydney, Australia
}

SUMMARY The treatment is described of 17 patients with presumed viral hepatitis who developed hepatic coma unresponsive to standard conservative measures. Five patients were considered for treatment by exchange transfusion. Four were treated, with transient improvement in two, but all died. Nine patients were considered for treatment by heterologous liver perfusion. Six were treated, with transient improvement in two and complete recovery in one. The last patient remains well 12 months later. Dialysis in four patients had no effect on the coma; the addition of albumin to the dialysate did not increase the extraction of bilirubin.

The clinical course in most cases was irregular. Complications were common, the most important being cerebral oedema with medullary coning, bleeding, bacterial infection, hypoglycaemia, and pancreatitis.

Heterologous liver perfusion was the most efficient method of removing bilirubin. However, it is not yet clear whether it is more effective than exchange transfusion in the treatment of the patient.

The development of coma in the course of acute viral hepatitis has a grave prognosis since it usually indicates extensive liver cell damage. However, the condition is potentially reversible, and a number of supportive measures have been advocated in an effort to maintain life until sufficient hepatic regeneration can occur to permit an unaided recovery (Benhamou, Rueff, and Sicot, 1968).

This paper describes our experience in the management of 17 patients with viral hepatitis who developed coma unresponsive to standard conservative measures. Initially exchange transfusion was used, but after disappointing results a trial of heterologous liver perfusion was begun.

\section{PATIENTS AND METHODS}

There were 10 female and seven male patients aged 5 to 56 years (Tables I to III). They were seen during a period of 30 months, during which time 1,040 patients were admitted to the Prince Henry Hospital with a diagnosis of viral hepatitis, and 20 of these patients died. The diagnosis was based on the clinical course and the absence of other known causes of acute hepatic failure.

The grading of coma was that used by the Fulminant Hepatic Failure Surveillance Study (Trey and Organizing Group, 1968) and can be summarized as follows: grade I is mood change and mild confusion; grade Il drowsy; grade III stuporose; and grade IV unrousable, except possibly by noxious stimuli.

All patients treated by exchange transfusion or liver perfusion had grade III or IV coma at the start of the procedure. All patients had clinical evidence of a haemorrhagic diathesis; the one-stage (Quick) prothrombin times ranged from 25 to 180 seconds (control 12 to 16 seconds). Hypokalaemia and hypoglycaemia, if present, had been corrected for at least 12 hours before exchange transfusion or liver perfusion.

The clinical course in most patients was one of overall progressive clinical deterioration, but with transient fluctuations in conscious state. Such fluctuations could not always be related to changes in therapy or to obvious complications of hepatic failure.

CONSERVATIVE TREATMENT All patients were treated with purgation, suspension of oral feeding, framycetin by nasogastric tube, and with fluids, electrolytes, and dextrose intravenously. Deficiencies of coagulation factors were treated with fresh-frozen plasma, fibrinogen, or human prothrombin complex concentrate (concentrate of factors II, VII, IX, and $X^{1}$ ). Four patients (nos. 2, 6, 7, and 15) were given corticosteroids.

EXCHANGE TRANSFUSION Five patients were considered for treatment by exchange transfusion (Table I). All were

${ }^{1}$ Obtained from Commonwealth Serum Laboratories, Parkhill, Victoria. 
TABLE I

PATIENTS CONSIDERED FOR TREATMENT BY EXCHANGE TRANSFUSION ${ }^{1}$

\begin{tabular}{|c|c|c|c|c|c|c|c|c|c|c|}
\hline $\begin{array}{l}\text { Patient } \\
\text { No. }\end{array}$ & $\begin{array}{l}\text { Age } \\
(y r)\end{array}$ & Sex & $\begin{array}{l}\text { Duration } \\
\text { of } \\
\text { Symptoms } \\
\text { (Days) }\end{array}$ & $\begin{array}{l}\text { Duration } \\
\text { of } \\
\text { Coma } \\
\text { (Days) }\end{array}$ & $\begin{array}{l}\text { Serum } \\
\text { Bilirubin } \\
(\mathrm{mg} / 100 \mathrm{ml})\end{array}$ & $\begin{array}{l}\text { Serum } \\
\text { Alanine } \\
\text { Amino- } \\
\text { transferase } \\
\text { (IU/litre) }\end{array}$ & $\begin{array}{l}\text { Serum } \\
\text { Albumin } \\
(\mathrm{g} / 100 \mathrm{ml})\end{array}$ & $\begin{array}{l}\text { Prothrombin } \\
\text { Time } \\
\text { (sec) }\end{array}$ & $\begin{array}{l}\text { Liver Weight } \\
\text { at Necropsy } \\
(\mathrm{g})\end{array}$ & Comment \\
\hline $\begin{array}{l}1 \\
2 \\
3 \\
4 \\
5\end{array}$ & $\begin{array}{l}19 \\
29 \\
51 \\
52 \\
40\end{array}$ & $\begin{array}{l}\mathbf{F} \\
\mathbf{M} \\
\mathbf{F} \\
\mathbf{M} \\
\mathbf{F}\end{array}$ & $\begin{array}{l}29 \\
10 \\
60 \\
38 \\
90\end{array}$ & $\begin{array}{c}8 \\
1 \frac{1}{6} \\
2 \\
22 \\
3\end{array}$ & $\begin{array}{l}43 \cdot 5 \\
15 \cdot 7 \\
24 \\
20 \\
33 \cdot 6\end{array}$ & $\begin{array}{r}69 \\
1,560 \\
202 \\
31 \\
455\end{array}$ & $\begin{array}{l}3 \cdot 4 \\
2 \cdot 9 \\
2 \cdot 7 \\
- \\
3 \cdot 2\end{array}$ & $\begin{array}{r}72 \\
70 \\
40 \\
80 \\
180\end{array}$ & $\begin{array}{r}425 \\
1,400 \\
650 \\
-\quad 800\end{array}$ & $\begin{array}{l}\text { Medullary coning three } \\
\text { hours before antici- } \\
\text { pated start of exchange }\end{array}$ \\
\hline
\end{tabular}

${ }^{1}$ Clinical details and biochemical values at start of treatment or at time of rejection for treatment.

TABLE II

PATIENTS CONSIDERED FOR TREATMENT BY HETEROLOGOUS LIVER PERFUSION ${ }^{1}$

\begin{tabular}{|c|c|c|c|c|c|c|c|c|c|c|}
\hline $\begin{array}{l}\text { Patient } \\
\text { No. }\end{array}$ & $\begin{array}{l}\text { Age } \\
(y r)\end{array}$ & Sex & $\begin{array}{l}\text { Duration } \\
\text { of } \\
\text { Symptoms } \\
\text { (Days) }\end{array}$ & $\begin{array}{l}\text { Duration } \\
\text { of } \\
\text { Coma } \\
\text { (Days) }\end{array}$ & $\begin{array}{l}\text { Serum } \\
\text { Bilirubin } \\
(\mathrm{mg} / 100 \mathrm{ml})\end{array}$ & $\begin{array}{l}\text { Serum } \\
\text { Alanine } \\
\text { Amino- } \\
\text { transferase } \\
\text { (IU/litre) }\end{array}$ & $\begin{array}{l}\text { Serum } \\
\text { Albumin } \\
(\mathrm{g} / 100 \mathrm{ml})\end{array}$ & $\begin{array}{l}\text { Prothrombin } \\
\text { Time } \\
\text { (sec) }\end{array}$ & $\begin{array}{l}\text { Liver Weight } \\
\text { at Necropsy } \\
(\mathrm{g})\end{array}$ & Comment \\
\hline 6 & 5 & $\mathbf{F}$ & 7 & 3 & $39 \cdot 2$ & 370 & $2 \cdot 7$ & 131 & - & \\
\hline 7 & 10 & $\mathbf{M}$ & 56 & 3 & $21 \cdot 3$ & 850 & $2 \cdot 2$ & 120 & - & \\
\hline 8 & 37 & $\mathbf{F}$ & 11 & 3 & $35 \cdot 2$ & 375 & $2 \cdot 8$ & 62 & 1,300 & \\
\hline 9 & 33 & $\mathbf{F}$ & 56 & 21 & $35 \cdot 0$ & 55 & $2 \cdot 4$ & 30 & 630 & Severe renal failure \\
\hline 10 & 16 & $\mathbf{M}$ & 14 & 4 & $30 \cdot 0$ & 360 & $3 \cdot 0$ & 120 & 890 & $\begin{array}{l}\text { Severe hypotension be- } \\
\text { fore perfusion due to } \\
\text { commence }\end{array}$ \\
\hline 11 & 36 & $\mathbf{M}$ & 35 & 3 & $40 \cdot 0$ & 585 & $3 \cdot 0$ & 25 & 1,950 & Severe renai failure \\
\hline 12 & 6 & $\mathbf{F}$ & 35 & 2 & $39 \cdot 0$ & 65 & $2 \cdot 8$ & 44 & - & \\
\hline 13 & 5 & $\mathbf{M}$ & 35 & 2 & $20 \cdot 4$ & 310 & $2 \cdot 5$ & 180 & - & Hypoglycaemia \\
\hline 14 & 40 & $\mathbf{P}$ & 14 & 5 & $29 \cdot 2$ & 948 & $2 \cdot 4$ & 34 & 600 & \\
\hline
\end{tabular}

${ }^{1}$ Clinical details and biochemical values at start of treatment or at time of rejection for treatment.

oliguric, and in all the liver was reduced in size. The serum bilirubin ranged from 15.7 to $43.5 \mathrm{mg} / 100 \mathrm{ml}$, and the serum alanine aminotransferase from 69 to $1,560 \mathrm{IU} /$ litre. One patient (no. 5) died suddenly of medullary coning due to cerebral oedema three hours before exchange transfusion was due to start.

Exchange transfusion was performed via polyethylene catheters in the median antecubital vein and the inferior vena cava. Either fresh heparinized blood or citrated blood collected within 72 hours was used (Table IV). Infusion and withdrawal were performed simultaneously. The rate of exchange of each litre of blood varied from 40 to 120 minutes, and the volume of blood used for each exchange ranged from $2 \cdot 5$ to 8 litres. At the end of each procedure, protamine, fibrinogen, or fresh-frozen plasma were given as indicated by tests of coagulation.

HETEROLOGOUS LIVER PERFUSION Nine patients were considered for treatment by liver perfusion (Table II). Three patients (nos. 9, 11, and 14) had oliguric renal failure. The liver was clinically reduced in size in all except nos. 7 and 13. The serum bilirubin ranged from 20.4 to $40.0 \mathrm{mg} / 100 \mathrm{ml}$ and the serum alanine aminotransferase from 55 to $948 \mathrm{IU} /$ litre. Two patients (nos. 9 and 11) were rejected because coma appeared to be principally due to renal failure. A third patient (no. 10) died from haemorrhagic shock (probably due to pancreatitis) while a pig's liver was being prepared.

The techniques for the liver perfusions have been described in detail previously (Ham, Pirola, Davidson, Yarrow, and Elmslie, 1968). The livers were excised from pigs weighing 20 to $30 \mathrm{~kg}$ after having been cooled and washed free of pig's blood. Each liver was then perfused in an isolated circuit with a heat exchanger and an oxygenator. The circuit was primed with blood compatible with that of the patient. The liver was warmed to $38^{\circ} \mathrm{C}$ and optimal liver blood flow and portal venous pressure were established. When the perfusion was stable and bile was flowing, the circuit was connected to the patient via an arteriovenous shunt in the brachial vessels. If the blood flow obtained from the brachial artery was less than that necessary to maintain liver blood flow, then the flow was supplemented by recirculation through the oxygenator (Fig. 1). This technique was important in treating children. Anticoagulation was achieved by systemic or regional heparinization. At the end of each procedure protamine, fibrinogen, or human prothrombin complex concentrate were given as indicated by coagulation tests.

DIALYSIS Three patients were treated for concomitant renal failure by peritoneal dialysis (Table III). Baxter dialysis solution was used in a volume of 2 litres per 


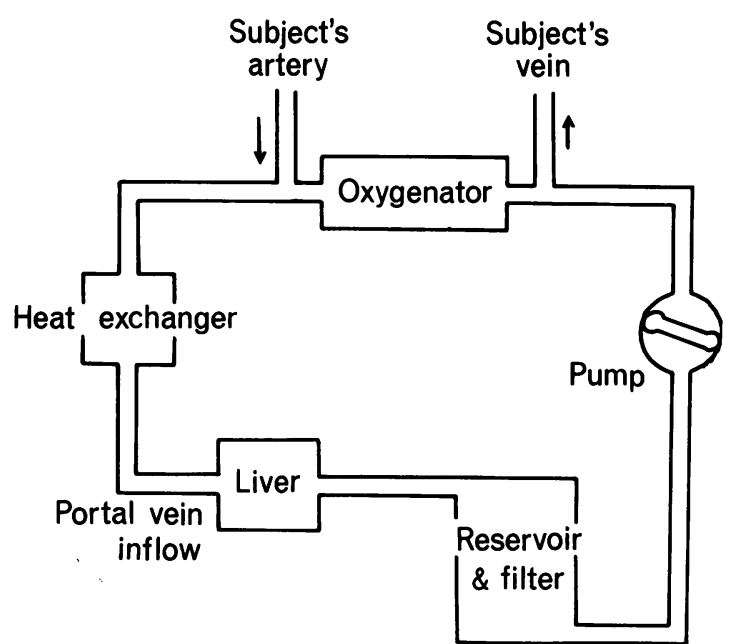

FIG. 1. Diagram of the circuit used in the treatment of patients by liver perfusion.

change in adults, and 1 litre per change in a child (no. 15); the dialysate was changed at hourly intervals. In a fourth patient (Table III), haemodialysis was performed for six hours with a Kolff twin-coil machine and the dialysate was changed two hourly. The effect of the addition of albumin to the dialysate on the removal of bilirubin was tested in these patients. In the peritoneal dialyses, albumin was added to two or more consecutive changes to give concentrations of $2 \cdot 0$ to $5 \cdot 2 \mathrm{~g} / 100 \mathrm{ml}$. In the haemodialysis, albumin was added to the second dialysis to give a concentration of $3 \mathrm{~g} / 100 \mathrm{ml}$. The bilirubin concentration in the serum and in the dialysate was measured before, during, and after the addition of albumin.

\section{RESULTS}

EXCHANGE TRANSFUSION Two patients showed a transient improvement (Table IV). In one (no. 3), the grade of coma improved from IV to II after the first exchange. There was no improvement with the second exchange and she died shortly afterwards from massive gastrointestinal haemorrhage. In the second patient (no. 4), the coma lightened from grade III to grade II after each of the first two exchanges, but no improvement was seen following the remaining two. He developed bronchopneumonia, and died. The remaining two patients showed no improvement and died shortly after the procedure. One of these (no. 2) had cerebral oedema with medullary coning at necropsy. In no patient was there any significant improvement in the electroencephalogram following the procedure.

Each exchange produced a sharp fall in the serum bilirubin concentration. This was followed by an equally sharp rebound, and in most instances the concentration returned to the pre-exchange value within 24 hours (Table IV).

TABLE III

DETAILS OF DIALYSES IN FOUR PATIENTS

\begin{tabular}{|c|c|c|c|c|c|c|c|c|}
\hline \multirow{2}{*}{$\begin{array}{l}\text { Patient } \\
\text { No. }\end{array}$} & \multirow{2}{*}{$\begin{array}{l}\text { Age } \\
(y r)\end{array}$} & \multirow[t]{2}{*}{$\operatorname{Sex}$} & \multirow{2}{*}{$\begin{array}{l}\text { Serum } \\
\text { Bilirubin } \\
(\mathrm{mg} / 100 \mathrm{ml})\end{array}$} & \multirow{2}{*}{$\begin{array}{l}\text { Serum } \\
\text { Albumin } \\
(\mathrm{g} / 100 \mathrm{ml})\end{array}$} & \multirow{2}{*}{$\begin{array}{l}\text { Type of } \\
\text { Dialysis }\end{array}$} & \multicolumn{3}{|c|}{ Bilirubin in Dialysate $(\mathrm{mg} / 100 \mathrm{ml})$} \\
\hline & & & & & & Before Albumin & $\begin{array}{l}\text { During Addition } \\
\text { of Albumin }\end{array}$ & After Albumin \\
\hline 2 & 29 & $\mathbf{M}$ & $15 \cdot 2$ & $2 \cdot 8$ & Haemodialysis & 0 & 0 & 0 \\
\hline 15 & 6 & $\mathbf{M}$ & $9 \cdot 7$ & $2 \cdot 9$ & Peritoneal & $0-0 \cdot 3$ & $0 \cdot 1-1 \cdot 0$ & $0.3-0.5$ \\
\hline $16(a)$ & 50 & $\mathbf{F}$ & 46 & $3 \cdot 7$ & Peritoneal & $0 \cdot 1$ & 0.2 & 0.4 \\
\hline (b) & - & - & 34 & $2 \cdot 8$ & Peritoneal & 1.4 & 0.3 & 0.1 \\
\hline 17 & 56 & $\mathbf{F}$ & $25 \cdot 6$ & $2 \cdot 7$ & Peritoneal & 0 & 0 & 0 \\
\hline
\end{tabular}

TABLE IV

RESULTS OF TREATMENT BY EXCHANGE TRANSFUSION

\begin{tabular}{|c|c|c|c|c|c|c|c|c|c|c|}
\hline \multirow{2}{*}{$\begin{array}{l}\text { Patient } \\
\text { No. }\end{array}$} & \multicolumn{2}{|c|}{ Exchange } & \multirow{2}{*}{$\begin{array}{l}\text { Type of } \\
\text { Blood }\end{array}$} & \multicolumn{2}{|c|}{ Depth of Coma } & \multicolumn{3}{|c|}{ Serum Bilirubin } & \multirow{2}{*}{$\begin{array}{l}\text { Survival } \\
\text { after Last } \\
\text { Exchange } \\
(\text { hr })\end{array}$} & \multirow[t]{2}{*}{ Comment } \\
\hline & No. & $\begin{array}{l}\text { Volume } \\
\text { (litres) }\end{array}$ & & Before & Lightest & Before & $\begin{array}{l}\text { Immediately } \\
\text { Afterwards }\end{array}$ & $\begin{array}{l}24 \text { Hours } \\
\text { Afterwards }\end{array}$ & & \\
\hline \multirow[t]{2}{*}{1} & 2 & 5 & Citrated & IV & IV & $43 \cdot 5$ & - & $22 \cdot 5$ & & $\begin{array}{l}\text { Miscarriage during first } \\
\text { exchange }\end{array}$ \\
\hline & & 8 & Heparinized & IV & IV & $28 \cdot 0$ & $4 \cdot 6$ & - & 10 & \\
\hline 2 & 1 & 4 & Citrated & IV & IV & $15 \cdot 7$ & $7 \cdot 4$ & $15 \cdot 2$ & 60 & $\begin{array}{l}\text { Medullary coning, } \\
\text { pancreatitis }\end{array}$ \\
\hline \multirow[t]{3}{*}{3} & 2 & $4 \cdot 5$ & Citrated & IV & II & $24 \cdot 6$ & $10 \cdot 0$ & $14 \cdot 8$ & 3 & $\begin{array}{l}\text { Died; diffuse gastro- } \\
\text { intestinal bleeding three } \\
\text { hours after exchange }\end{array}$ \\
\hline & & $\begin{array}{l}6 \\
6 \\
6\end{array}$ & $\begin{array}{l}\text { Citrated } \\
\text { Heparinized } \\
\text { Heparinized }\end{array}$ & $\begin{array}{l}\text { III } \\
\text { III } \\
\text { III }\end{array}$ & $\begin{array}{l}\text { II } \\
\text { II } \\
\text { III }\end{array}$ & $\begin{array}{l}35 \cdot 2 \\
32 \cdot 8 \\
31 \cdot 0\end{array}$ & $\begin{array}{l}20 \cdot 5 \\
20 \cdot 4 \\
25 \cdot 4\end{array}$ & $\begin{array}{l}32 \cdot 8 \\
31 \cdot 0 \\
35 \cdot 2\end{array}$ & & \\
\hline & & $2 \cdot 5$ & Heparinized & IV & IV & $35 \cdot 2$ & $24 \cdot 8$ & - & 18 & $\begin{array}{l}\text { Bronchopneumonia, liver } \\
\text { increasing in size }\end{array}$ \\
\hline
\end{tabular}


TABLE V

RESULTS OF TREATMENT BY LIVER PERFUSION

\begin{tabular}{|c|c|c|c|c|c|c|c|c|c|}
\hline \multirow{2}{*}{$\begin{array}{l}\text { Patient } \\
\text { No. }\end{array}$} & \multicolumn{2}{|c|}{ Perfusions } & \multicolumn{2}{|c|}{ Depth of Coma (Grade) } & \multicolumn{3}{|c|}{ Serum Bilirubin } & \multirow{2}{*}{$\begin{array}{l}\text { Survival } \\
\text { after Last } \\
\text { Perfusion }\end{array}$} & \multirow[t]{2}{*}{ Comment } \\
\hline & No. & $\begin{array}{l}\text { Duration } \\
(\min )\end{array}$ & Before & Lightest & Before & $\begin{array}{l}\text { Immediately } \\
\text { After }\end{array}$ & $\begin{array}{l}24 \text { Hours } \\
\text { After }\end{array}$ & & \\
\hline \multirow[t]{2}{*}{6} & 2 & 240 & IV & III & $35 \cdot 7$ & 8.0 & $14 \cdot 0$ & & \multirow{7}{*}{$\begin{array}{l}\text { Acute brain stem syndrome } \\
\text { Alive } \\
\text { Retroperitoneal haemorrhage }\end{array}$} \\
\hline & & 300 & IV & IV & $14 \cdot 0$ & $5 \cdot 7$ & $7 \cdot 8$ & $36 h r$ & \\
\hline 7 & 1 & 240 & IV & III & $21 \cdot 3$ & $4 \cdot 1$ & $11 \cdot 7$ & $12 \mathrm{mth}$ & \\
\hline 8 & 1 & 180 & IV & IV & $33 \cdot 8$ & $5 \cdot 7$ & - & $1 \frac{1}{2} h r$ & \\
\hline \multirow[t]{3}{*}{12} & 3 & 60 & III & II & $32 \cdot 0$ & 14.0 & 22.0 & & \\
\hline & & 53 & IV & III & $22 \cdot 0$ & $9 \cdot 2$ & $18 \cdot 8$ & & \\
\hline & & 120 & IV & IV & $18 \cdot 8$ & $9 \cdot 6$ & - & $4 h r$ & \\
\hline \multirow[t]{2}{*}{13} & 2 & 180 & IV & III & $20 \cdot 4$ & $4 \cdot 8$ & $11 \cdot 1$ & & \multirow{3}{*}{ Hypoglycaemia } \\
\hline & & 195 & IV & IV & $17 \cdot 4$ & $7 \cdot 4$ & $12 \cdot 6$ & $27 h r$ & \\
\hline 14 & 1 & 120 & IV & IV & $29 \cdot 2$ & $16 \cdot 6$ & $18 \cdot 4$ & $27 \mathrm{hr}$ & \\
\hline
\end{tabular}

Local complications included wound infection in one patient and femoral vein thrombosis in another. Three patients had a moderate to severe thrombocytopenia $(13,000$ to $80,000 / \mathrm{cmm})$ after the procedure. In one patient (no. 3), exchange transfusion may have precipitated massive bleeding.

HETEROLOGOUS LIVER PERFUSION Ten perfusions were performed in six patients, the duration of the perfusions ranging from 53 to 300 minutes (Table V). One patient, a 10-year-old child, recovered (no. 7). His level of consciousness improved from grade IV to III in the first hour of perfusion and then showed no change for four hours. A steady improvement then began and he was fully conscious 36 hours later. This neurological improvement was maintained despite a gradual rise in serum bilirubin level to $27 \mathrm{mg} /$ $100 \mathrm{ml} 14$ days later. Thereafter hepatic function improved steadily and he was discharged two months later. He subsequently developed a febrile illness which may have represented an immunological disturbance secondary to the perfusion (Harris, 1968). Treatment with azathioprine was associated with a complete remission, and he remains well nine months later.

The remaining patients died. One (no. 12) improved with each of the first two perfusions (grade IV to II and grade IV to III), and became so restless with the first treatment that light anaesthesia with nitrous oxide was necessary. There was no improvement with the third perfusion. The first perfusion in two other patients (nos. 6 and 13) also produced lightening of the coma. However, subsequent perfusions in these patients, and those performed in the remaining two patients (nos. 8 and 14), had no obvious effect. These latter perfusicns were all performed when the electroencephalogram showed transient complete absence of activity. In no case was there any appreciable increase in urine flow as a result of the perfusion.

Each perfusion produced a sharp reduction in serum bilirubin, maximal in the first hour. This was partly due to haemodilution; however, the rebound after perfusion was delayed when compared with exchange transfusion (Table $\mathrm{V}$ ), indicating a considerably more efficient extraction of total body bilirubin.

The major complications of the perfusions were related to disorders of blood coagulation. Patient no. 8 developed a massive retroperitoneal haematoma due to leakage from the site of a femoral arterial puncture. Four perfusions had to be stopped prematurely because of clotting in the circuit. In one instance this was apparently due to inadequate heparin dosage. In the remaining three the clotting followed the infusion of human prothrombin complex concentrate into the patient in an attempt to minimize the risk of bleeding. These were the only perfusions in which the concentrate was administered. We have now reserved its use for the period immediately following the perfusion. Moderate to severe thrombocytopenia developed in three patients $(21,000$ to 70,000 platelets/cmm). Patient no. 6 appeared to develop sudden medullary coning due to cerebral oedema half an hour after the second perfusion. However, a necropsy was not performed, and the possibility of a brain-stem haemorrhage cannot be excluded.

There were no other major complications in the patients, but it is noteworthy that a nursing member of the perfusion team developed a mild attack of viral hepatitis two months after one of the perfusions. This was despite the administration of gammaglobulin to all members of the team at the time of each perfusion.

DIALYSIS The concentration of bilirubin in the dialysate was always low. Minor fluctuations could be explained by slight bleeding from the peritoneal catheter wound. The addition of albumin to the dialysis fluid had no effect on the removal of bilirubin (Table III). In no case did dialysis produce any 
obvious clinical improvement or any change in the serum bilirubin level.

\section{DISCUSSION}

The patients described in this report developed a variety of severe complications. These included cerebral oedema, bleeding, bacterial infection, hypoglycaemia, and pancreatitis. Thus, the course of the illness in these patients was very irregular, adding to the problems of timing and assessment of therapy. Cerebral oedema with medullary coning is not a recognized complication of hepatic failure, but has been reported in association with viral hepatitis (Lucké, 1944). It was the immediate cause of death in at least two patients reported here (nos. 2 and 5) and probably also occurred in a third (no. 6). A fourth patient (no. 15) had severe cerebral oedema without medullary coning.

Disorders of blood coagulation are a major clinical problem in hepatic failure and may be further aggravated by exchange transfusion or liver perfusion. Bleeding was a major factor contributing to the death of two of the present patients (nos. 3 and 8). We feel it is important to minimize the risk of inducing bleeding by avoiding percutaneous puncture of large vessels and suction on nasogastric tubes.

Hypoglycaemia occurred in one of the present patients (no. 13) and may have been present for some hours before it was recognized. Subsequently large doses of glucose were required to maintain an adequate concentration in the blood. In this patient, brain damage due to hypoglycaemia may have prevented clinical improvement during perfusion.

Acute pancreatitis is a recognized but uncommon complication of infectious hepatitis (Achord, 1968). Haemorrhagic pancreatitis was found at necropsy in two of our patients; in one (no. 10) it appeared to be a major factor contributing to death. Some degree of renal dysfunction was present in most of the patients reported here. However, dialysis in four patients had no influence on the patients' coma, and the addition of albumin to the dialysate did not improve the removal of bilirubin. The level of bilirubin in the serum may be of little direct importance in hepatic coma. However, its removal is of interest since it is a protein-bound substance normally removed by the liver and it has been suggested that hepatic coma may result from the accumulation of protein-bound 'toxic' substances (Jones, Clain, Clink, MacGillivray, and Sherlock, 1967).

The assessment of therapy for hepatic failure complicating acute liver disease is difficult for other reasons apart from the unpredictable course of the illness. These include lack of knowledge of the mechanisms responsible for coma, the relatively small number of patients seen by any one unit, and the absence of a biochemical test that correlates reliably with the degree of hepatic coma or with the severity of liver cell damage. The difficulties in assessing therapy are exemplified by the contrasting claims made for a variety of supportive measures used in hepatic failure (Benhamou et al, 1968). There is a need for combined studies, provided that uniform methods for assessing patients can be defined.

In the present study, all patients had presumed viral hepatitis, and all had deepening coma despite a full trial of standard conservative treatment; a fatal outcome was expected in each. The transient improvements in patients nos. $3,4,6,12$, and 13 , and the full recovery in patient no. 7 , are therefore encouraging. In the latter patient, there were three favourable prognostic points, namely, hepatomegaly, a serum bilirubin of only $21.3 \mathrm{mg} / 100 \mathrm{ml}$, and a high serum alanine aminotransferase (850 IU/litre). Most patients had small livers at the time of the first exchange transfusion or liver perfusion, although two (nos. 7 and 13) had enlarged livers which subsequently shrank in size. In the surviving patient, the serum bilirubin was lower, and the serum alanine aminotransferase higher, than in most of the other patients. On the other hand, the serum alanine aminotransferase had fallen by $300 \mathrm{IU} /$ litre in the 24 hours before liver perfusion. In our experience, such a fall, combined with a rising serum bilirubin concentration and deepening coma, is almost inevitably fatal.

In this patient, liver biopsy one month after perfusion showed that there was still extensive hepatocellular damage, but there was only minimal periportal fibrosis. A second biopsy six months later showed no increase in the fibrosis. In the necropsies on fatal cases the degree of hepatic damage was variable, but in all cases was severe and associated with a distorted architecture. It would appear that some degree of cirrhosis would have been inevitable if these patients had survived.

The variety of complications seen in severe viral hepatitis, and the consequently irregular course of the illness, make it impossible for any one unit to have sufficient patients to carry out a controlled trial of new forms of therapy. In the absence of controls the selection of patients is critical. The method of selection of patients for exchange transfusion and liver perfusion in this study was such that a high percentage of survivals would have been a strong indication that the special therapeutic measures used had been effective. Such a cautious approach seemed to be particularly indicated in the application of a new technique such as liver perfusion. However, this method of selection created further problems. In 
some patients deterioration was so rapid that at the start of liver perfusion there were already intermittent episodes when electrical activity was absent from the electroencephalogram. In view of this, and of the low incidence of major complications from the special procedures used, it would seem desirable to start the procedures earlier.

The present results suggest that both methods have some effect on the course of the illness. However, the data are inadequate to distinguish which method is the better except that liver perfusion was more efficient in the removal of bilirubin.

We thank the Clinical Liver Research Fund of the Prince Henry Hospital for its assistance, Mr R. Stacey and the staff of the Experimental Surgical Laboratories for their help, Dr B. Billington for his advice and encouragement, and the physicians who referred the cases.

\section{REFERENCES}

Achord, J. L. (1968). Acute pancreatitis with infectious hepatitis. J. Amer. med. Ass., 205, 837-840.

Benhamou, J. P., Rueff, B., and Sicot, C. (1968). Etude critique des traitements actuels de l'insuffisance hépatique grave. Rev. frans. Etud. clin. biol., 13, 651-658.

Ham, J. M., Pirola, R. C., Davidson, G. M., Yarrow, S., and Elmslie, R. G. (1968). Pig liver perfusion for the treatment of acute hepatic coma. Surg. Gynec. Obstet., 127, 543-549.

Harris, M. J. (1968). Problems in the survival of a patient after acute hepatic necrosis treated by heterologous liver perfusion. Proc. 3rd Asian Pacific Congr. Gastroent., 1, 39-45.

Jones, E. A., Clain, D., Clink, H. M., MacGillivray, M., and Sherlock, S. (1967). Hepatic coma due to acute hepatic necrosis treated by exchange blood-transfusion. Lancet, 2, 169-172.

Lucké, B. (1944). The pathology of fatal epidemic hepatitis. Amer. J. Path., 20, 471-593.

Trey, C., and Organizing Group (1968). Second Progress Report: Fulminant Hepatic Failure Surveillance Study, Boston. Thorndike Memorial Laboratory, Boston City Hospital. 